\title{
KEKUATAN TARIK HASIL PENGELASAN SMAW PLAT BAJA ST 37 DENGAN PENDINGIN LIQUID
}

\section{THE TENSILE STRENGTH OF SMAW STEEL PLATE WELDED ST 37 WITH LIQUID COOLERS}

\author{
${ }^{1}$ Dicky Adi Tyagita, ${ }^{2}$ Andik Irawan \\ Program Studi Mesin Otomotif Jurusan Teknik Politeknik Negeri Jember \\ Jl. Mastrip Kotak Pos 164 Sumbersari Jember \\ dicky.tyagita@gmail.com
}

\begin{abstract}
Abstrak
Teknik pengelasan telah banyak diaplikasikan pada penyambungan logam dengan maksud untuk mendapatkan hasil sambungan yang lebih ringan dan lebih sederhana tetapi memiliki kekuatan yang tidak kalah dengan jenis pemyambungan logam lainnya.Pengelasan adalah ikatan metalurgi pada sambungan logam paduan yang terjadi dalam keadaan lumer atau cair, dengan kata lain pengelasan adalah penyambungan setempat dari dua logam dengan mengguanakan energi panas. Energi panas ini dapat rekayasa atau dikondisikan sedemikianrupa untuk membentuk materialproperties. Materialproperties merupakan salah satu acuan dalam bidang teknik material dan manufaktur dalam penentuan kelayakan material hasil pengelasan. Perlakuan pendinginan hasil pengelasan memegang peranan penting dalam terbentuknya struktur dasar material yang akan menentukan material properties. Salah satu material properties adalah kekuatan tarik. Penelitian ini bertujuan untuk membandingkan nilai kekuatan tarik hasil pengelasanSMAWplat baja ST 37 dengan pendinginan cairan radiator coolant $(R C)$ dan oli SAE $10 \mathrm{~W}-40$. Melalui penelitian ini dapat diketahui cairan pendingin mana yang mampu memberikan nilai kekuatan tarik tertinggi. Setelah melakukan pengujian dan pembahasan diketahui bahwa mengunakan cairan oli sebagai pendigin dengan cara mencelupkan hasil lasan hingga dingin memiliki nilai kekuatan tarik tertinggi yaitu sebesar $144,27 \mathrm{~kg} / \mathrm{mm}^{2}$.
\end{abstract}

Kata kunci : Las, Oli, Radiator Coolant

\begin{abstract}
Welding technique has been applied to the metal connection with the intent to get the connection that is lighter and simpler, but has a power that is not inferior to other types of metal connection. Welding is a metallurgical bond on alloy metal joints that occur in the molten or liquid state, in other words, welding is local connection of two metal by using thermal energy. This thermal energy can be modified or conditioned in such a way to form the material properties.Material properties is a reference in the field of materials engineering and manufacturing techniques in determining the feasibility of the weld material. The treatment of the weld cooling are important role in the formation of the basic structure of the material that will determine the material properties.One material properties are tensile strength. This research aims to compare the tensile strength results SMAW welding steel plates ST 37 with a liquid cooling system with radiator coolant (RC) and oil SAE 10W - 40.Through this research can know where the cooling liquid is capable of providing the highest tensile strength values.After testing and study known that with use oil as a cooler by dipping welds to cold has the highest tensile strength values of $144.27 \mathrm{kgf} / \mathrm{mm}^{2}$.
\end{abstract}

Key words :Weld, Oil, Radiator Coolant

\section{PENDAHULUAN}

Di era globalisasi sekarang ini setiap individu dituntut untuk selalu mengikuti kemajuan ilmu pengetahuan dan teknologi. Kemajuan ilmu pengetahuan dan teknologi ini terlihat dari kemampuan individu untuk terus mengembangkan teknologi penyam-bungan logam yang salah satu diantaranya adalah teknologi pengelasan. Kualitas dari hasil pengelasan sangat dipengaruhi oleh persiapan pelaksanaan dan pengerjaan serta proses perlakuan pendinginan terhadap logam yang dilas. Sehingga untuk mendapatkan hasil sambungan pengelasan yang baik dan berkualitas maka perlu 
memperhatikan sifat-sifat bahan yang akan dilas maupun penelitian tentang perlakuan pendinginan pada logam yang dilas sangat mendukung untuk mendapatkan hasil sambungan las yang berkualitas.

Media pendingin yang lazim digunakan untuk mendinginkan spesimen pada proses pengelasan antara lain oli, air, larutan garam dan gas. Dalam penelitian Ardiansyah tentang variasi pendinginan terhadap hasil pengelasan SMAW plat baja ST 37 menyimpulkan nilai tegangan tarik rata-rata pada spesimen dengan pendinginan udara normal yaitu $32,62 \mathrm{kgf} / \mathrm{mm}^{2}$. Nilai tegangan tarik rata-rata untuk spesimen dengan pendingin air selama 1 detik yaitu $3,03 \mathrm{kgf} / \mathrm{mm}^{2}$. Terjadi penurunan sebesar $90,71 \%$ dari pendinginan udara normal. Sedangkan pendinginan air selama 5 detik memiliki tegangan tarik rata-rata sebesar 23,01 $\mathrm{kgf} / \mathrm{mm}^{2}$. Mengalami penurunan tegangan sebesar $29,46 \%$ dari pendinginan udara normal. 30,31 $\mathrm{kgf} / \mathrm{mm}^{2}$ adalah nilai tegangan tarik pada pendinginan air penuh. Mengalami penurunan sebesar $7,08 \%$ dari nilai tegangan tarik pada pendinginan udara normal. perlakuan pendinginan air 1 detik, 5 detik dan dicelup sampai dingin menyebabkan spesimen menjadi getas, hasil pendinginan udara normal nilai tegangan dan regangannya lebih tinggi terhadap kekuatan tarik menggunakan jenis kampuh las $\mathrm{V}$ ganda.

Imbarko di tahun 2010 meneliti mengenai pengaruh perlakuan panas pada hasil pengelasan plat baja ST 37 dalam penelitiannya menyimpulkan bahwa nilai kekuatan tarik pada metal dasar $46,05 \mathrm{kgf} / \mathrm{mm}^{2}$. Nilai kekuatan tarik paling terendah $33,13 \mathrm{kgf} / \mathrm{mm}^{2}$ terjadi pada perlakuan pelunakan yang berarti mengalami penurunan sebesar 28,06 \% dari kelompok metal dasar. Sedangkan kekuatan tarik yang paling tinggi terjadi pada perlakuan pengerasan dengan media pendingin Oli Mesran SAE 40 sebesar $49,53 \mathrm{kgf} / \mathrm{mm}^{2}$ yang berarti mengalami peningkatan kekuatan tarik 7,56\% dari metal dasar. Tipe sambungan butt joint menggunakan las SMAW DC.

Sukamto (2009) dalam penelitiannya menyimpulkan dari hasil pengujian tarik diketahui bahwa pada logam induk sebelum pengelasan mempunyai tegangan tarik sebesar $34,63 \mathrm{kgf} / \mathrm{mm}^{2}$. Pada benda uji setelah pengelasan menggunakan proses pendinginan air mempunyai tegangan tarik sebesar $20,25 \mathrm{kgf} / \mathrm{mm}^{2}$, regangan 4,58 \%. Dengan pendinginan udara mempunyai tegangan tarik $22,75 \mathrm{kgf} / \mathrm{mm}^{2}$, regangan $5 \%$. Dengan pendinginan air laut mempunyai tegangan tarik $27,07 \mathrm{kgf} / \mathrm{mm}^{2}$, regangan 9,46\%. Bahan yang digunakan plat baja karbon rendah, bentuk kampuh V tunggal dengan las TIG (Tungsten Inert Gas).
Penelitian ini dilakukan bertujuan untuk tegangan tarik dan kekerasan baja karbon rendah ST 37 dengan harapan penggunaan baja karbon rendah menjadi lebih luas dengan pertimbangan harga masih relatif murah dibandingkan dengan jenis baja karbon lain. Dalam penelitian ini, cairan radiator coolant dipilih karena memiliki kandungan air murni, Etilen glikol dan anti-karat. Sebagai pembanding, media pendingin oli digunakan karena mempunyai sifat dan laju pendinginan yang berbeda, sehingga bila diketahui tingkat perbandingan kekuatan tariknya dan kesesuaiannya terhadap aplikasi dan kegunaannya, maka dapat diambil suatu keputusan untuk menggunakan proses perlakuan pendinginan pada media yang tepat, agar menghemat waktu dan biaya produksi.

Atas dasar itulah maka penulis menitik beratkan pada penelitian Kekuatan Tarik Hasil Pengelasan SMAW Plat Baja ST 37 Dengan Pendingin Liquid sehingga kesimpulan akhir dari hasil yang didapatkan bisa memberikan informasi dan masukan pada masyarakat yang bermanfaat yaitu perlakuan pendinginan terhadap logam yang dilas sehingga memiliki material properties yang sesuai harapan. Tujuan dalam penelitian ini adalah:membandingkan nilai kekuatan tarik hasil pengelasanSMAWplat baja ST 37 dengan pendinginan cairan radiator coolant $(R C)$ dan oli SAE 10W - 40.

\section{TINJAUAN PUSTAKA \\ Pengelasan}

Las SMAW (Shielded Metal Arc Welding) yaitu penyambungan dua buah logam atau lebih menjadi satu dengan jalan pelelehan atau pencairan dengan busur nyala listrik. Jadi las listrik atau las busur listrik merupakan proses penyambungan logam dengan memanfaatkan tenaga listrik sebagai sumber panasnya. Pengelasan dengan mengguanakan tenaga listrik sebagai sumber panas dapat dibedakan menjadi dua macam yaitu las tahanan listrik dan las busur nyala listrik (Marwanto, 2007).

\section{Pendinginan}

Dalam proses pendingin media pendingin yang sering digunakan sebagai pendingin yaitu air, air garam, oli dan udara. Semakin cepat logam didinginkan maka akan semakin keras sifat logam itu, karbon yang dihasilkan dari pendinginan cepat lebih banyak dari pendingian lambat. Dengan alasan media pendingin tersebut digunakan sesuai dengan kemampuannya untuk memperoleh hasil yang diharapkan. (Wiryosumarto, 2000)

Pada tabel 1 di bawah ini dapat terlihat nilai tetapan fisik seperti densitas, viskositas dll. media pendinginair. 
Tabel 1. Tetapan fisik air pada temperature tertentu

\begin{tabular}{lllll}
\hline Tetapan fisik & \multicolumn{1}{c}{$0^{\circ}$} & \multicolumn{1}{c}{$20^{\circ}$} & \multicolumn{1}{c}{$50^{\circ}$} & $100^{\circ}$ \\
\hline Massa jenis $\left(\mathrm{g} / \mathrm{cm}^{3}\right)$ & 0.9997 & 0.99823 & 0.9981 & 0.9584 \\
Panas jenis (kal/g. $\left.{ }^{\circ} \mathrm{C}\right)$ & 1.0074 & 0.9988 & 0.9985 & 1.0069 \\
\hline Kalor uap (kal/g) & 597.3 & 586.0 & 569.0 & 539.0 \\
\hline Konduktifitas thermal & $1.39 \times 10^{-3}$ & $1.40 \times 10^{-3}$ & $1.52 \times 10^{-3}$ & $1.63 \times 10^{-3}$ \\
(kal/cm.s. ${ }^{\circ} \mathrm{C}$ ) & & & & \\
\hline Tegangan permukaan & 75.64 & 72.75 & 67.91 & 58.80 \\
(dyne/cm) & & & & \\
Laju viskositas (g/cm.s) & $178.34 \times 10^{-4}$ & $100.9 \times 10^{-4}$ & $54.9 \times 10^{-4}$ & $28.4 \times 10^{-4}$ \\
\hline Tetapan dielektrik & 87.825 & 80.8 & 69.725 & 55.355 \\
\hline
\end{tabular}

Sumber: (Firmansyah, 2014)

Faktor - faktor yang mempengaruhi laju pendinginan media pendingin.

1. Densitas

Semakin tinggi densitas suatu media pendingin, maka semakin cepat proses pendinginan oleh media pendingin tersebut. Air memiliki densitas tinggi, pendinginan dengan menggunakan air akan memberikan daya pendinginan yang cepat sehingga dapat mengakibatkan spesimen menjadi getas.

\section{Viskositas}

Viskositas adalah sebuah ukuran penolakan sebuah fluid terhadap perubahan bentuk di bawah tekanan shear, Semakin tinggi viskositas suatu media pendingin, maka laju pendinginan semakin lambat, Air memiliki viskositas rendah, sedangkan minyak sayur memiliki viskositas tinggi. (Sanusi, 2014)

Oli memiliki nilai viskositas atau kekentalan yang tertinggi dibandingkan dengan media pendingin lainnya dan massa jenis yang rendah sehingga laju pendinginannya lambat. Angka di belakang huruf SAE inilah yang menunjukkan tingkat kekentalannya (viskositas). Contohnya, kode SAE 10 menunjukkan oli tersebut mempunyai tingkat kekentalan 10 menurut standar SAE. Semakin tinggi angkanya, semakin kental pelumas tersebut

Kemampuan suatu jenis media dalam mendinginkan spesimen bisa berbeda-beda, perbedaan kemampuan media pendingin di sebabkan oleh temperatur, kekentalan, kadar larutan dan bahan dasar media pendingin. Pelumas adalah minyak yang mempunyai sifat untuk selalu melekat dan menyebar pada permukaan-permukaan yang bergeser, sehingga membuat pengausan dan kenaikan suhu kecil sekali.

Selama proses pemanasan dan pendinginan tersebut, akan terjadi beberapa perubahan ukuran butiran dan struktur mikro. Karena semakin tinggi temperatur austenisasi diberikan pada material yang sama ukuran butir akan semakin besar. Dan dengan harga laju pendinginan yang bervariasi material yang sama akan mempunyai struktur mikro yang berbeda, dapat berupa fineferritpearlit, medium ferrit-pearlit, coarseferrit-pearlit, bainit atupun martensit. (Yuwono, 2009)

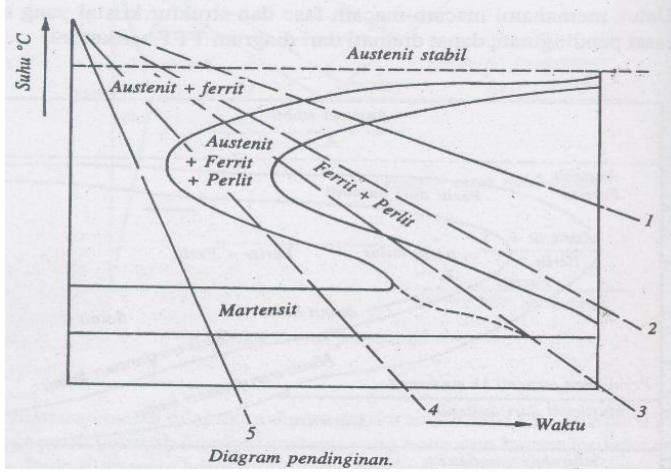

Gambar 1. Diagram perlakuan pendinginan. Sumber : Anrinal, 2013

\section{Kegagalan}

Suatu material dikatakan gagal jika tegangan yang di izinkan melebihi dari hasil tes/uji. Jika tegangan yang dihitung melebihi tegangan yang diizinkan diasumsikan kegagalan dari material (material failure) terjadi.

Kegagalan pada suatu material dapat terjadi dalam berbagai wujud. Misalnya retak, patah, korosi dan lain sebagainya. Penyebab kegagalan juga bermacam-macam seperti misalnya salah desain, kesalahan maintenance, cacat material, temperatur, waktu dan lain-lainnya. alam bab ini hanya akan dibahas kegagalan material yang diakibatkan oleh kekuatan tarik (tensile strength).

Uji tarik merupakan salah satu pengujian untuk mengetahui sifat-sifat suatu bahan. Dengan menarik suatu bahan kita akan segera mengetahui bagaimana bahan tersebut bereaksi terhadap tenaga tarikan dan mengetahui sejauh mana material itu bertambah panjang. Sesuai dengan Hukum Hooke (Hooke's Law) hubungan antara beban atau gaya yang diberikan berbanding lurus dengan perubahan panjang bahan tersebut. Ini disebut daerah linier atau linear zone. Di daerah ini, kurva pertambahan panjang vs beban mengikuti aturan Hooke yaitu rasio tegangan (stress) dan regangan (strain) adalah konstan seperti pada gambar 2 di bawah ini.

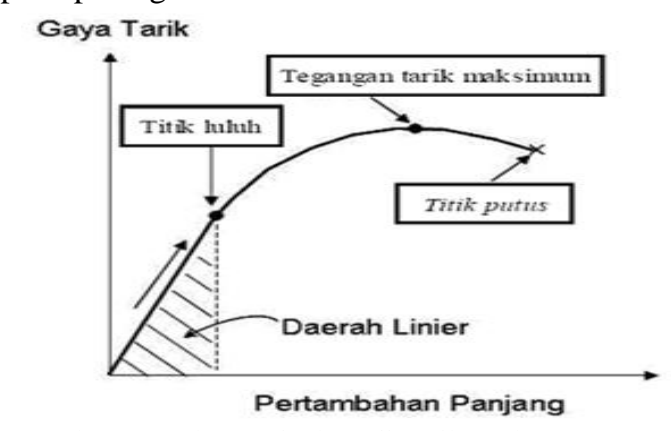

Gambar 2.Gambaran Singkat Uji TarikSumber: Yuwono, 2009 
Aturan Hooke menyatakan: Stress adalah beban dibagi luas penampang bahan. Strain adalah pertambahan panjang dibagi panjang awal bahan.

\section{METODOLOGI}

Metode yang digunakan dalam penelitian ini adalah metode eksperimental, yaitu metode yang digunakan untuk menguji material dengan cara uji tarik, namun sebelum dilakukan pengujian tarik material dipotong sesuai dimensi dan dibuat sudut kampuh tertentu dan kemudian dilakukan pengelasan dibagian sudut kampuhnya. Pengujian tarik menggunakan mesin Universal Testing Machine Model TM 113 ESSO di laboratorium Mesin Otomotif.

Bahan yang telah dipersiapkan dipotong dengan panjang $200 \mathrm{~mm}$, dan tebal baja karbon rendah $10 \mathrm{~mm}$, menggunakan gerinda potong. Pembuatan spesimen uji tarik ini sesuai standar JIS Z 22011981 sebanyak 12 spesimen. Adapun diagram alir penelitian dalam proses uji tarik dapat terlihat pada gambar 2 di bawah ini. Setelah spesimen pengelasan dibentuk sesuai spesifikasi yang ditentukan, spesimen tersebut di las dan dikenai perlakuan pendinginan menggunakan radiator coolant dan oli. Setelah itu hasil pengelasan dibentuk dengan standart JIS 2201, dan di uji tarik.

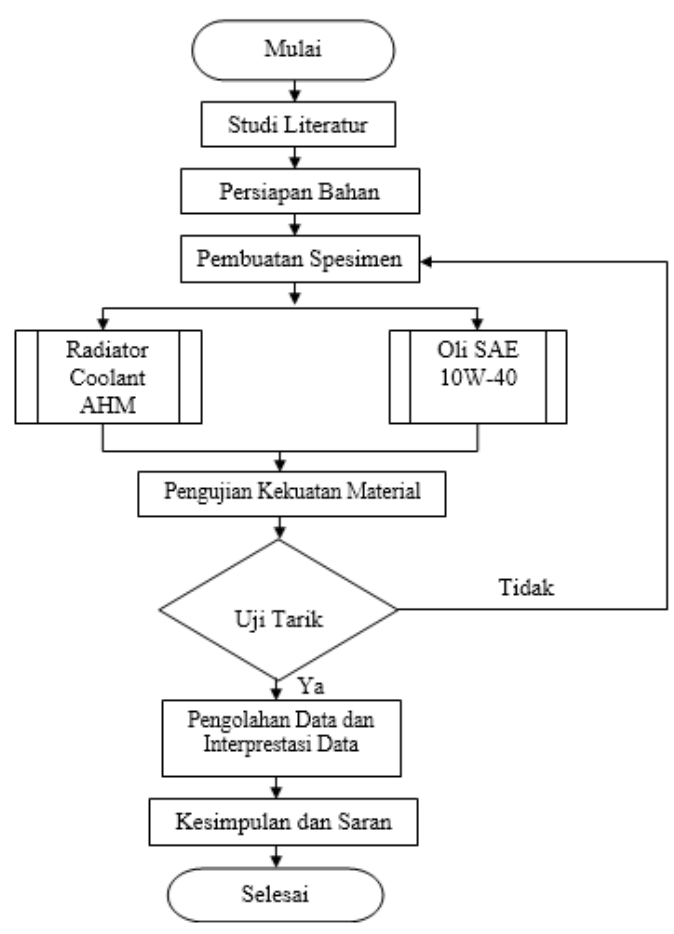

Gambar 3. Diagram alir penelitian

A. Tahapan Penelitian

Bahan yang telah dipersiapkan dipotong dengan panjang $200 \mathrm{~mm}$, dan tebal baja karbon rendah $10 \mathrm{~mm}$, menggunakan gerinda potong. Pembuatan spesimen uji tarik ini sesuai standar JIS Z 22011981 sebanyak \pm 12 spesimen seperti pada gambar 3 berikut ini.

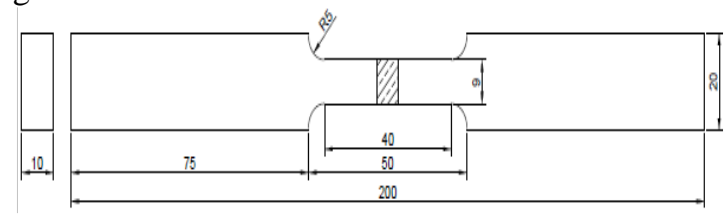

Gambar 3. Spesimen JIS Z 22011981

Keterangan:

$$
\begin{aligned}
& \mathrm{L}_{\mathrm{o}}=\text { Panjang Spesimen Uji }=200 \mathrm{~mm} \\
& \mathrm{~W}_{\mathrm{o}}=\text { Lebar Awal }=20 \mathrm{~mm} \\
& \mathrm{t} \quad=\text { Tebal Pelat Baja }=10 \mathrm{~mm}
\end{aligned}
$$

Pembuatan Kampuh

Setelah pembuatan spesimen uji tarik selesai dilakukan, selanjutnya dilakukan pembuatan kampuh $\mathrm{V}$ dengan kemiringan sudut $60^{\circ}$. Dengan spesifikasi sebagai berikut:

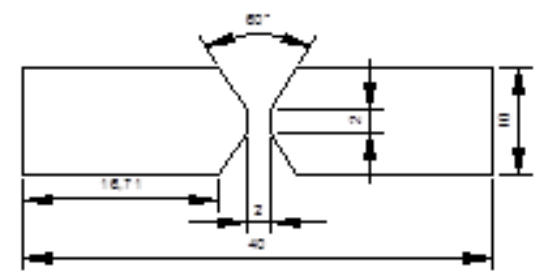

Gambar 4. Kampuh V ganda

Sumber: Mohammad Nuh, 2013

\section{Pengelasan Benda Uji}

Setelah benda uji selesai dibuat, selanjutnya dilakukan pengelasan pada benda uji dengan ketentuan sebagai berikut:

a. Material yang di las plat baja St 37 .

b. Arus listrik yang digunakan AC / 125 amper.

c. Jenis elektroda yang digunakan Familiarc RB$26 \varnothing 3,2 \mathrm{~mm}$. Klasifikasi JIS E 4313 dan AWS E 6013. Tipe Covering High Titania. Penggunaan untuk (Mild Steel).

d. Jenis kampuh yang digunakan $\mathrm{V}$ ganda.

e. Posisi pengelasan $1 \mathrm{G}$ yaitu posisi datar.

Proses Pendinginan Benda Uji

Setelah dilakukan pengelasan pada benda uji, saat suhu benda uji masih panas maka dilakukan perlakuan pendinginan dengan cairan radiator coolant, oli SAE 10W- 40 masing-masing dengan tahap sebagai berikut:

a. Pendinginan dengan cairan radiator coolant, oli SAE 10W - 40 selama 5 detik yaitu benda kerja setelah mengalami proses pengelasan dicelupkan kedalam cairan radiator coolant, oli SAE 10W - 40 masing-masing selama 5 detik.

b. Pendinginan cairan radiator coolant, oli SAE 10W - 40 total yaitu setelah benda kerja di las 
Dicky Adi Tyagita, Andik Irawan, Kekuatan Tarik HAsil Pengelasan SMAW Plat Baja ST 37 Dengan Pendingin Liquid

maka di celupkan sedalam cairan radiator coolant, oli SAE 10W - 40 masing-masing sampai dingin.

c. Memberikan tanda dengan spidol pada masingmasing spesimen sesuai dengan perlakuan pendinginan.

Pengujian Kekuatan Material

Pada tahapan pengujian kekuatan material ini dilakukan tes uji kekuatan tarik (tensile strength). Tujuan dari hasil tes ini untuk menentukan sifat dari material tersebut. Artinya menentukan seberapa kuat material ini. Untuk mengetahui rencana hasil penelitian ini adapun langkahlangkah dan tabel 3.1 dapat dilihat di bawah ini.

a. Menandai benda kerja las yang didinginkan dengan cairan radiator coolant, oli SAE 10W 40 selama 5 detik dan didinginkan dengan cairan radiator coolant, oli SAE 10W - 40 sampai dingin.

b. Menentukan ukuran panjang, tinggi dan lebar benda kerja.

c. Memasang benda uji pada pencekam dan pastikan pencekam dapat mencekam benda uji dengan baik.

d. Menyalakan indicator pada mesin uji tarik.

e. Catat pembebanan yang diberikan dan pertambahan panjang pada benda kerja dan dapat digunakan kamera digital untuk merekam.

f. Setelah benda uji patah, lepaskan benda uji dari pencekam.

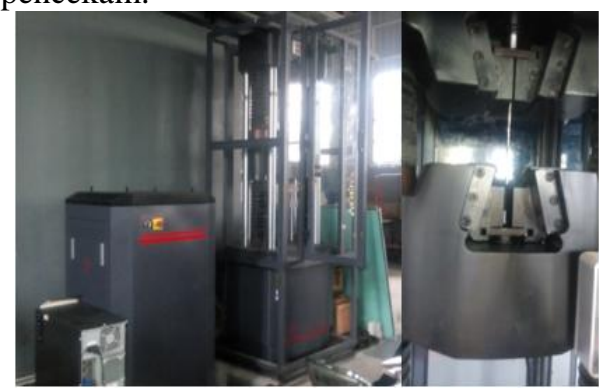

Gambar 5. Universal testing machine dan proses pengujian tarik

\section{HASIL DAN PEMBAHASAN}

A. Nilai Hasil Pengujian Material

Setelah melakukan pengujian pengujian tarik yang dilakukan di Laboratorium Otomotif Politeknik Negeri Jember, maka didapatkan nilai tegangan tarik $(\sigma)$ seperti pada gambar 6- 8 di bawah ini.

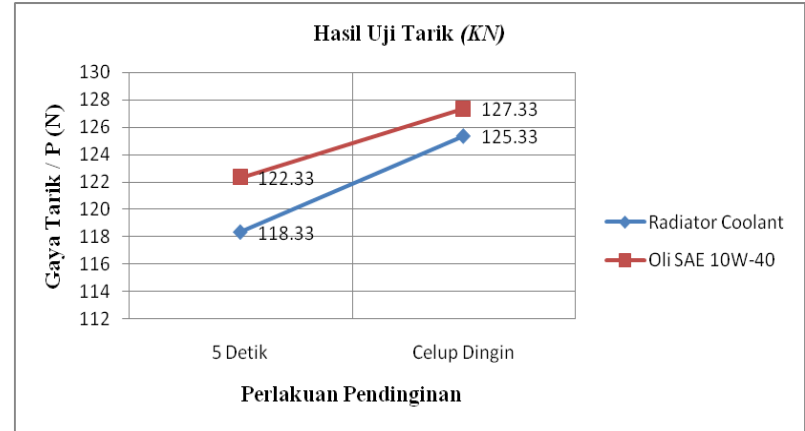

Gambar 6. Grafik rata-rata hasil uji tarik media pendingin

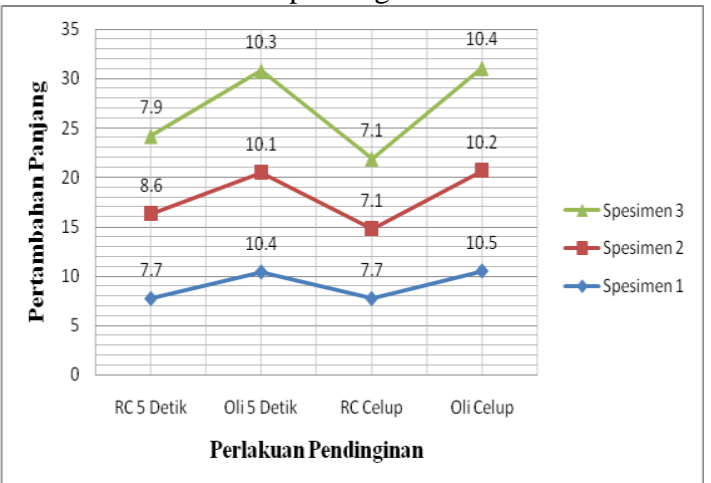

Gambar 7.Perubahan panjang masing-masing spesimen/ $\Delta \mathrm{L}(\mathrm{mm})$

Dari gambar 7, grafik di atas didapatkan nilai rata - rata dari pertambahan panjang spesimen sebagai berikut:

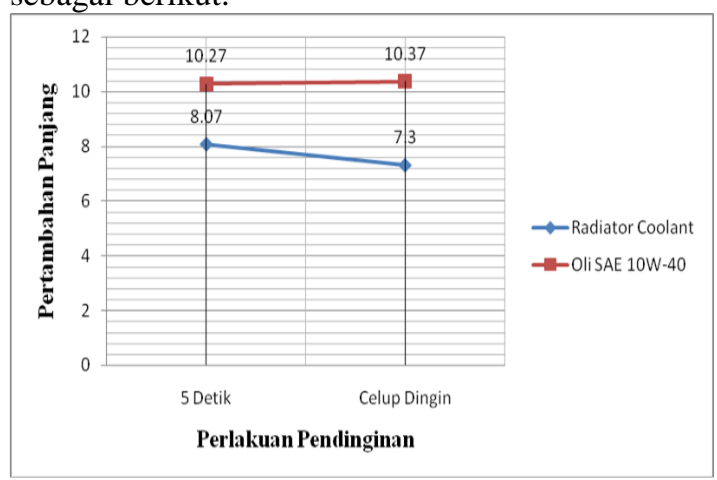

Gambar 8. Grafik rata-rata perubahan panjang/ $\Delta \mathrm{L}(\mathrm{mm})$

Dari grafik di atas terlihat pada perlakuan pendinginan menggunakan oli dicelup sampai dingin memiliki nilai pertambahan panjang tertinggi yaitu $10,37 \mathrm{~mm}$ mengalami peningkatan 0,1 $\mathrm{mm}$ dari pendinginan Oli 5 detik.. Sedangkan pada perlakuan pendinginan Radiator Coolant dicelup sampai dingin memiliki nilai pertambahan panjang yang paling terendah yaitu $7,3 \mathrm{~mm}$ dari pendinginan RC 5 detik yaitu 8,07 $\mathrm{mm}$ mengalami penurunan sebesar $0,77 \mathrm{~mm}$ dari pendinginan $\mathrm{RC}$ 5 detik. Sementara Radiator Coolant 5 detik mengalami penurunan sebesar 2,2 mm dari nilai

perlakuan pendinginan Oli 5 detik yaitu 10,27 $\mathrm{mm}$. Nilai pertambahan panjang rata-rata terendah 
didapat oleh perlakuan pendinginan $\mathrm{RC}$ dicelup sampai dingin yaitu $7,3 \mathrm{~mm}$ mengalami penurunan sebesar $3,07 \mathrm{~mm}$ dari perlakuan pendinginan Oli dicelup sampai dingin yaitu 10,37 $\mathrm{mm}$.

Setelah melakukan pengujian dan mengetahui hasil pengujian tarik, maka dapat ditentukan tegangan tarik $(\sigma)$, regangan $(\varepsilon)$, dan modulus elastisitas (E) dengan rumus:

Tegangan Tarik $\sigma=\frac{P_{\max }}{A}=\frac{p}{b \cdot \hat{k}}$

Dimana: $\sigma \quad=$ Tegangan tarik $\left(\mathrm{kgf} / \mathrm{mm}^{2}\right)$

$\mathrm{P}_{\max } \quad=$ Gaya tarikan maksimum $(\mathrm{N})$

A $\quad=$ Luas penampang $\left(\mathrm{mm}^{2}\right)$

$\mathrm{b}=$ Lebar $\left(\mathrm{mm}^{2}\right)$

$\mathrm{h} \quad=$ Tebal $\left(\mathrm{mm}^{2}\right)$

Dengan menggunakan rumus di atas maka besar tegangan tarik dari masing-masing spesimen dapat diketahui, seperti pada Tabel 2.

Tabel 2. Hasil Perhitungan Tegangan

\begin{tabular}{|c|c|c|c|c|}
\hline \multirow{2}{*}{ Spesimen } & \multicolumn{4}{|c|}{ Tegangan Tarik $\left(\mathbf{k g} / \mathbf{m m}^{2}\right)$} \\
\cline { 2 - 5 } & & \multicolumn{4}{|c|}{ Perlakuan Pendinginan } \\
\cline { 2 - 5 } & RC 5 detik & Oli 5 detik & RC celup & Oli celup \\
\hline 1 & 133,79 & 139,35 & 142,73 & 145,02 \\
\hline 2 & 134,83 & 138,26 & 141,64 & 142,73 \\
\hline 3 & 133,79 & 138,26 & 141,64 & 145,02 \\
\hline Total & 402,41 & 415,87 & 426,01 & 432,77 \\
\hline Rata-Rata & 134,17 & 138,63 & 142,03 & 144,27 \\
\hline
\end{tabular}

Dari hasil perhitungan Tegangan Tarik di atas, selanjutnya didapatkan hasil grafik nilai rata - rata Tegangan Tarik dari masing-masing perlakuan pendinginan sebagai berikut:

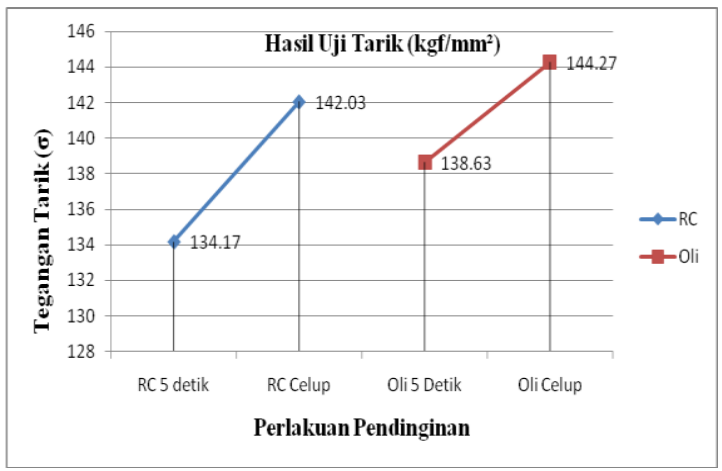

Gambar 9. Grafik tegangan rata - rata hasil uji tarik

Dari grafik di atas terlihat nilai rata-rata tegangan tarik pada perlakuan pendinginan Oli dicelup sampai dingin memiliki nilai tegangan tertinggi yaitu sebesar $144,27 \mathrm{kgf} / \mathrm{mm}^{2}$ mengalami peningkatan $5,64 \mathrm{kgf} / \mathrm{mm}^{2}$ dari perlakuan pendinginan Oli 5 detik yaitu 138,63 $\mathrm{kgf} / \mathrm{mm}^{2}$. Sedangkan Radiator Coolant dicelup sampai dingin memiliki nilai tegangan rata-rata 142,03 $\mathrm{kg} / \mathrm{mm}^{2}$ mengalami peningkatan $7,86 \mathrm{kgf} / \mathrm{mm}^{2}$ dari perlakuan pendinginan RC 5 detik yaitu 134,17 $\mathrm{kgf} / \mathrm{mm}^{2}$. Sementara perlakuan pendinginan Oli dicelup sampai dingin mengalami peningkatan sebesar 2,24kgf/ $\mathrm{mm}^{2}$ dari perlakuan pendinginan RC dicelup sampai dingin yaitu 142,03 $\mathrm{kgf} / \mathrm{mm}^{2}$.
Nilai tegangan rata-rata terendah didapat oleh perlakuan pendinginan RC 5 detik yaitu 134,17 $\mathrm{kgf} / \mathrm{mm}^{2}$ mengalami penurunan sebesar 4,46 $\mathrm{kgf} / \mathrm{mm}^{2}$ dari perlakuan pendinginan Oli 5 detik yaitu $138,63 \mathrm{kgf} / \mathrm{mm}^{2}$.

\section{KESIMPULAN}

Setelah melakukan pembahasan terhadap data hasil pengujian tarik terhadap plat baja ST 37 dengan perlakuan pendinginan Radiator Coolant (RC) AHM dan Oli SAE 10W - 40 maka dapat diambil beberapa kesimpulan sebagai berikut:

1. Pada hasil pengelasan dengan perlakuan pendinginan Oli dicelup sampai dingin nilai Tegangan dan Regangannya lebih tinggi dibandingkan dengan perlakuan pendinginan RC 5 detik, Oli 5 detik dan RC dicelup sampai dingin;

2. Pada perlakuan pendinginan RC dicelup sampai dingin spesimen memiliki Regangan paling rendah dikarenakan laju pendinginannya lebih cepat, adanya tegangan sisa yang tinggi sehingga memiliki sifat mudah patah getas;

3. Perlakuan pendinginan RC 5 detik, Oli 5 detik dan RC dicelup sampai dingin dapat menyebabkan spesimen menjadi sangat getas;

4. Pada hasil pengelasan dengan perlakuan pendinginan $\mathrm{RC}$ dicelup sampai dingin nilai Modulus Elastisitasnya lebih tinggi dibandingkan dengan pendinginan RC 5 detik, Oli 5 detik dan Oli dicelup sampai dingin.

\section{UCAPAN TERIMA KASIH}

Penulis mengucapkan terimakasih kepada Politeknik Negeri Jember selaku penyandang dana BOPTN sehingga Program Penelitian Dosen Pemula ini dapat terlaksana.

\section{DAFTAR PUSTAKA}

Anrinal., (2013). Metalurgi Fisik. Yogyakarta: CV Andi Offset.

Ardiansyah., (2010). Pengaruh Variasi Pendinginan Terhadap Kekuatan Tarik Hasil Pengelasan SMAW Pada Plat Baja St 37. Skripsi Universitas Muhammadiyah Jember.

Firmansyah., (2014). Analisis Efektivitas Laju Pembuangan Panas Fluida Air Dengan Radiator Coolant (RC) Pada Sepeda Motor. Skripsi Universitas Jember.

Imbarko., (2010). Studi Pengaruh Perlakuan Panas Pada Hasil Pengelasan Baja St 37 Ditinjau Dari Kekuatan Tarik Bahan. Universitas Sumatera Utara Medan

Marwanto., (2007). Shield Metal Arc Welding. Universitas Negeri Yogyakarta. 
Dicky Adi Tyagita, Andik Irawan, Kekuatan Tarik HAsil Pengelasan SMAW Plat Baja ST 37 Dengan Pendingin Liquid

Sanusi., (2014). Pengaruh (Heat Treatment) Terhadap Kekerasan (Hardness) Material Al 6061, dengan Pendingin Air, Oli, Air garam. Skripsi Universitas Muhammadiyah Jember.

Sukamto., (2009). Pengaruh Media Pendingin Terhadap Hasil Pengelasan TIG Pada Baja Karbon Rendah. Jurnal Volume 11 Nomor 2 Juli.

Wiryosumarto.H., dan Okumura.T., (2000). Teknologi Pengelasan Logam. Jakarta: Pradnya Paramita.

Yuwono., (2009). Buku Panduan Praktikum Karakterisasi Material 1. Depok: Departemen Metalurgi dan Material Fakultas Teknik Universitas Indonesia. 